Section Editors

David C. Spencer, MD

Steven Karceski, MD

John W. Henson, MD, FAAN

Bart P. Keogh, MD, $\mathrm{PhD}$

\title{
Plasticity
}

\section{Teaching an old brain new tricks}

WHAT DID THE AUTHORS STUDY? Dr. Duggal and his coauthors ${ }^{1}$ studied changes in the size of areas in the brain controlling motor and sensory function in patients whose spinal cords were compressed-or squeezed-in the neck. This compression was caused by deterioration in the vertebra and discs. Normally, the motor control areas of the brain send signals down the spinal cord to the muscles in the body, and sensory nerve impulses are conducted up the spinal cord into the brain. The authors used a technique called fMRI (see explanation below) to see how the brain might respond if some of the signals were blocked in the spinal cord. The changes in brain function in these patients should be easy to study because there is no direct damage to the brain. Thus any changes should all be due to effect on the spinal cord pathways.

WHAT DID THE AUTHORS FIND? In patients with spinal cord compression, the motor control area in the brain was larger than usual and the sensory control area was smaller than normal. One explanation for this is that more of the brain is needed to make up for the decreased motor nerve conduction in the spinal cord. This is a form of "plasticity," or the ability of the brain to change in response to new demands (see "About Plasticity" page). The smaller sensory area could be explained by the fact that movement is required to activate sensory impulses in an fMRI study. Since there was less movement due to weakness, sensory activation would be lessened and thus the brain area would be smaller.

Surprisingly, once these same patients had surgery on their necks to relieve the compression, the enlarged motor control area became even larger. The reason for this is a mystery. However, it may be that the larger areas of activation in the brain are required for relearning how to use the weakened muscles. The amount of the brain necessary to learn a new task, like a new language, is at first quite large. After practice, it becomes smaller. The authors also found that the sensory control area also enlarged back to normal size after surgery.

WHAT DO THESE RESULTS MEAN FOR PATIENTS? These results show "plasticity" in motor and sensory control areas. As usual, the results raise new questions. How does this happen? How can these changes be harnessed to promote better function in patients who have suffered strokes or brain injury? As these questions are answered, the day when plasticity is used to treat human disability draws nearer. 
Section Editors

David C. Spencer, MD

Steven Karceski, MD

John W. Henson, MD, FAAN

Bart P. Keogh, MD, $\mathrm{PhD}$

\section{About plasticity}

WHAT IS PLASTICITY? The term plasticity describes the various ways in which the nervous system can change its function as a result of training, or in response to injury. ${ }^{2}$ An example is the steady improvement in skill with a task over about 4 weeks of daily practice. Those who brush their teeth using a side-to-side motion, for instance, will initially feel clumsy with an up-and-down or a circular motion. After practice, the new motion seems natural. This learning is due to rearrangement of how the brain handles its functions. Part of the improvement experienced by a patient following a stroke is similar. These are examples of plasticity.

HOW DOES PLASTICITY OCCUR? Plasticity can occur in many ways. There can be increased activity of the nerve cells that are already assigned to the task. New contacts can develop between nerve cells that are close to each other. Nerve cells from another part of the brain but with a similar function can be recruited to help.

WHY IS PLASTICITY IMPORTANT? Plasticity is one of the most fascinating mysteries of the human central nervous system. The brain was once thought to develop and then never change. But now many types of changes are known to occur, including the birth of new brain cells and the steady loss of brain cells in adulthood. Plasticity is another type of change that occurs in the adult brain. Plasticity means that people can start running marathons at 50 years of age, go back to school or learn a new job, or recover brain and bodily function after a stroke or spinal cord injury.

HOW IS PLASTICITY MEASURED? Changes in neurologic function due to plasticity can be measured by a neurologist in the clinic. These are standardized tests that result in a numerical score (for physical strength, for instance) that measure the changes. Recently, some new tests allow changes in function to be found in other ways. The following three tests are used the most:

- Functional MRI (see below)

- Magnetoencephalography, a specialized way of measuring subtle changes in brain electrical activity with electrodes placed on the scalp

- Transcranial magnetic stimulation, in which a small electrical shock is administered to the brain to slow down or start function

Functional MRI (fMRI) techniques can measure levels of "metabolic activity" in specific areas within the brain. Metabolic activity is the reaction between the chemicals and pathways in our bodies that help us live. This kind of measurement is possible because the oxygen-carrying molecule in blood, called hemoglobin, produces a different signal on MRI scans depending on whether or not it is bound to oxygen. In the motor area of the brain, there is a high level of metabolic activity during movement. For example, there is a lot of activity in the motor control area during finger tapping and the

Figure Motor control areas in the right precentral gyrus activated during finger tapping with the left hand

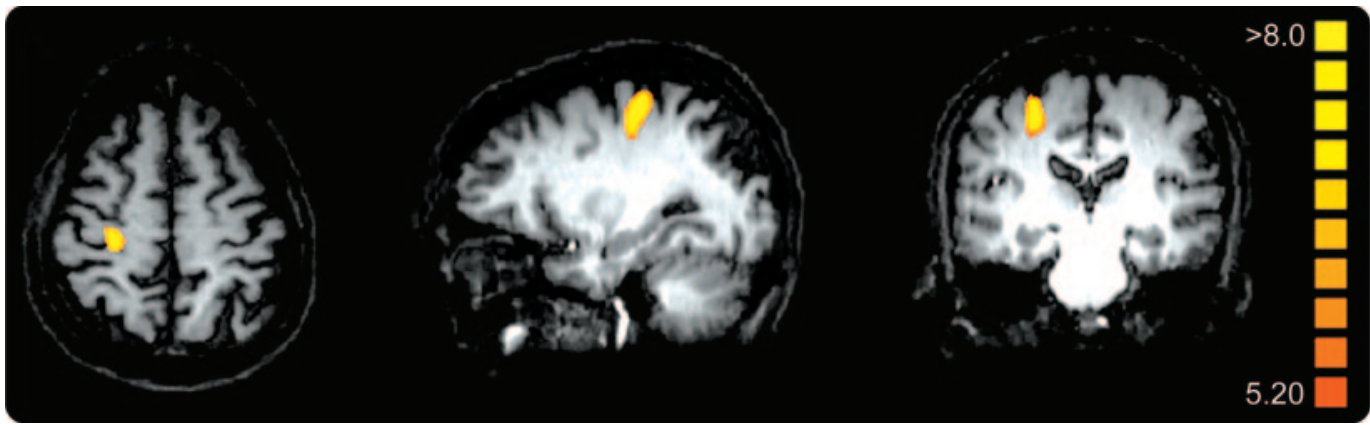

From Duggal et al. ${ }^{1}$ 
oxygen concentration falls. This is followed by an increase in blood flow and an increase in oxygen in the tissue. $\mathrm{fMRI}$ can detect these changes, and thus can provide an actual picture of plasticity (figure) as the functional areas change in size. ${ }^{1}$

FOR MORE INFORMATION

AAN.com for Patients \& Caregivers

http://patients.aan.com/go/home

Christopher and Dana Reeve Foundation

http://www.christopherreeve.org

National Rehabilitation Information Center (NARIC)

http://www.naric.com
Spinal Cord Society

http://scsus.org

Clearinghouse on Disability Information

http://www.ed.gov/about/offices/listlosers

National Institute on Disability and Rehabilitation Research (NIDRR)

http://www.ed.gov/about/offices/listlosers/nidrr

\section{REFERENCES}

1. Duggal N, Rabin D, Bartha R, et al. Brain reorganization in patients with spinal cord compression evaluated using fMRI. Neurology 2010;74:13;1048-1054.

2. Rossini PM, Altamura C, Ferreri F, et al. Neuroimaging experimental studies on brain plasticity in recovery from stroke. Eura Medicophys 2007;43:241-254. 


\title{
Neurology
}

\author{
Plasticity: Teaching an old brain new tricks \\ John W. Henson and Bart P. Keogh \\ Neurology 2010;74;e53-e55 \\ DOI 10.1212/WNL.0b013e3181d7b472
}

This information is current as of March 29, 2010

\section{Updated Information \& Services}

Supplementary Material

References

Subspecialty Collections

Permissions \& Licensing

Reprints including high resolution figures, can be found at: http://n.neurology.org/content/74/13/e53.full

Supplementary material can be found at: http://n.neurology.org/content/suppl/2011/04/18/74.13.e53.DC1

This article cites 2 articles, 1 of which you can access for free at: http://n.neurology.org/content/74/13/e53.full\#ref-list-1

This article, along with others on similar topics, appears in the following collection(s):

All Rehabilitation

http://n.neurology.org/cgi/collection/all_rehabilitation

\section{All Spinal Cord}

http://n.neurology.org/cgi/collection/all_spinal_cord

Plasticity

http://n.neurology.org/cgi/collection/plasticity

Information about reproducing this article in parts (figures,tables) or in its entirety can be found online at:

http://www.neurology.org/about/about_the_journal\#permissions

Information about ordering reprints can be found online: http://n.neurology.org/subscribers/advertise

Neurology ${ }^{\circledR}$ is the official journal of the American Academy of Neurology. Published continuously since 1951, it is now a weekly with 48 issues per year. Copyright . All rights reserved. Print ISSN: 0028-3878. Online ISSN: 1526-632X.

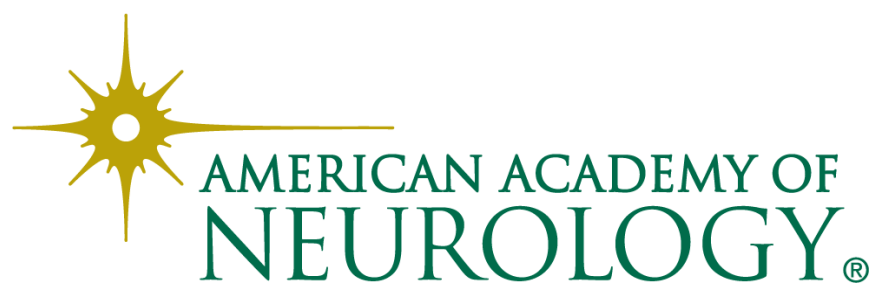

